\title{
A SURVEY OF JURY VERDICTS IN THE NORTHWEST TERRITORIES
}

\author{
W. G. MORROW*
}

\begin{abstract}
Sixty-eight criminal charges in all have been tried before jury during the fourteen years the Territorial Court of the Northwest Territories has operated. The writer has presided as judge on twenty-five of these and before that appeared as defence counsel on six. With a personal knowledge of almost one-half the total tried and with ready access to information relating to the others, this short survey or analysis has been attempted to see if any pattern of behaviour in juries can be readily ascertainable. Notes made at the trial, the actual court register and court files have all been examined. The writer has also called upon the phenomenal memory of Everett Tingley who served as court reporter for thirteen of the fourteen years. Alexander Stewart, the present Clerk of the Court and for many years before that a member of the R.C.M.P. serving in some of the Arctic communities involved, was also questioned on some of the cases.
\end{abstract}

In the Northwest Territories six jurors constitute a Jury. ${ }^{1}$ To serve a juror must be twenty-one years of age or over, be a Canadian or British citizen, and able to speak and understand the English language. There are certain exemptions and disqualifications set forth in the legislation. ${ }^{2}$ Until 1965 women were prohibited from serving. ${ }^{3}$ The first woman to actually serve as a juror was in a case at Spence Bay in April 1966. ${ }^{4}$

The policy of the Court has been to insist, where practicable, that an accused be tried in his own community. This policy has been adhered to by both judges of the Court.

In empanelling a jury in some of the smaller and more remote northern communities the Court has been forced to be flexible in applying the rules and tests laid down in the legislation. As much as possible natives ${ }^{s}$ people are called for jury duty although language does cut down the number of eligible jurors. This becomes readily apparent when the numbers who have actually served on juries is examined. It will be seen that natives have only appeared on some twenty-seven juries so far despite the court's efforts to include them. And of this number, only six juries have had three or more on them. To date there have been only two all native juries and these in the Western region. It is highly unlikely that an all native jury will be possible in either the Central or East Arctic for many years to come. As yet only the school-age Eskimos are showing any real proficiency in English. The few juries having natives on them have been possible due in no small degree to the co-operation of the Crown Attorney and defence ccunsel in not being too technical in respect to the panel.

Because of cultural and dialect differences, not to mention the remoteness of most of the Arctic communities, jurymen are pretty well

* The Honourable Mr. Justice W. G. Morrow, Judge of the Territorial Court of the Northwest Territories.

1 Criminal Code, S.C. 1953-54, c. 51, s. 541

2 Jury Ordinance, R.O.N.W.T., 1956, c. 55.

3 Jury Ordinance, Amendment, O.N.W.T., 1956 (2nd) c. 6.

Miss D. M. Koenig, $R$. v. Shooyook et al (unreported).

s In this article "native" includes: Eskimo, Indian, Metis. 
drawn locally. In the case of the trial of $R$. v. Shooyook et al, which was held at Spence Bay, only two English speaking Eskimo jurymen could be found, and this after the sheriff made a sweep of some fifteen hundred miles around the various communities in the Court plane looking for English-speaking Eskimo jurymen to serve. Judge Sissons felt, and all counsel agreed with him, that the above case in particular required that a special effort be made to have as many Eskimos as possible on the jury as the case involved construing Eskimo culture and ethics in relationship to what in effect was a community execution.

It is now proposed to examine some of the main headings of crime. (1) Murder: Except for the two persons charged with non-capital murder in 1966, these charges were all capital murder under the old provisions of the code where the penalty was death. ${ }^{\circ}$

In respect to the six cases which concerned Eskimos, an examination of the files discloses that in all but one, the charges arose from circumstances in which the cultural problems of a still primitive people were involved. The one exception arose out of an Eskimo shooting a policeman while escaping custody after having been arrested for intoxication. ${ }^{7}$

In the Shooyook case, supra, the two accused had been instructed by their chief or elder to execute an insane woman who was on a rampage that threatened the security of the whole community and under circumstances where it was impossible to obtain outside help. The jury in acquitting one of the accused and in finding manslaughter in respect to the other coupled with a strong recommendation for mercy, was undoubtedly mindful of the peculiar cultural problems involved. This approach was apparent from some of the questions directed to the presiding Judge after his charge to them, the questions being directed to what responsibility the chief had in the matter.

No all-white jury has to date convicted an Eskimo accused.

The case involving a white accused in 1961 was retried later as a manslaughter case and resulted in a second conviction of manslaughter. ${ }^{8}$ (2) Rape: Out of a total of sixteen persons tried only four were convicted as charged. Eight were acquittals. Perhaps the most interesting item here is that on the four cases where women sat on the jury there was no conviction.

When the court instructed the clerk to call women equally with men, for jury duty, defence counsel, especially, expressed some anxiety. It was apparent that in the first trial with women on the panel defence counsel made every effort to keep women off while the Crown Attorney if anything tried to get them on. The same anxiety does not seem to prevail anymore.

It may be that with women serving now, the jury for the first time is better able to assess the motivations as between complainant and accused. Alcohol and some preliminary encouragement from the complainant figured in each of the ten rape cases that has been tried before the writer.

(3) Indecent Assault and Attempted Rape: The observations made in

6 Criminal Code, S.C. 1953-54, c. 51, s. 206.

7 R. v. Ayalik (1960-61) 33 W.W.R. 377.

8 Brown v. The Queen [1962] S.C.R. 371, 37 C.R. 101, 132 C.C.C. 59. 
the paragraph immediately above could be repeated with respect to at least five of these cases tried before the writer. Two resulted in convictions in 1966. One of these was a completely unwarranted attack on a young native girl by a native. In the second one the complainant was an Indian girl while the accused was white. The all white jury in that case brought in a conviction.

General Summary:

1. Whether the jury is all white or not does not appear to affect the treatment of natives accused of crimes.

2. Even where the accused is white and the complainant is native an allwhite jury does not appear to show any racial prejudice.

3. If any trend is discernable, all-white juries seem to show more leniency towards native accused, particularly where the case involves cultural and sociological factors.

4. There appears to be an unwillingness to convict of murder.

5. All-native juries may have a more flexible attitude in sex cases. This may only be the result of the code provisions not necessarily corresponding with the native culture and attitudes relating to the submissiveness of the female.

6. The placing of women on juries on rape and related cases does not appear to have in any way resulted in an increase in convictions.

\section{Conclusion:}

In the two rape cases where all native juries were empanelled the writer would have been inclined to convict whereas the jury acquitted in each case. The complainant was an Indian in both while one accused was Eskimo and the other Indian. The circumstances in each instance showed the complainant placing herself in a position where if she did not actually invite the attack she might reasonably have expected it. Perhaps the jury knew its own people better than the judge. Certainly the verdicts in each case appear to have satisfied the community which is not without significance.

Examining all the other cases with which the writer had any connection there is only one in which he would have convicted where the jury did not. That was a rape case. The jury brought in a verdict of attempted rape. On reflection the writer is not disposed to disagree. It may well be that the jury was closer to the mark.

Except for three, therefore, the writer accepts the verdicts. In thirty-one cases in which the writer was involved, there was no case where the jury convicted where in the writer's opinion it should not have. Again the writer understands from his predecessor that although there may have been one or two acquittals he did not like, there was never a conviction he objected to.

If the above cases are any test, therefore, then certainly it can be said that in the Northwest Territories, at any rate, the jury provides a reliable and trustworthy method of handling trials for serious offences. So long as no one appears to be unjustly convicted surely there should be little dissatisfaction if one or two accused persons may possibly escape improperly.

There can be no doubt that in several of the cases, had it been trial by Judge alone, the Judge would in all conscience have had to convict. e.g. The Shooyook trial, supra, in pure law should have resulted in two men or perhaps the whole community being convicted of murder. Fortunately for Canada the jury system permitted a relaxation of the law so that a just decision could be arrived at. 
If justice is our concern, rather than the strict letter of the law, and the writer believes this is and should be our main concern, then certainly the jury system must be preserved. It is the law's best safety valve. The experience in the Northwest Territories to date at any rate would appear to bear out Lord Devlin's remarks when he says; "by far the greater purpose that is served by trial by jury is that it gives protection against laws which the ordinary man may regard as harsh and oppressive." 10 
TABLE I

JURY TRIALS-NORTHWEST TERRITORIES (1955-1968)

\begin{tabular}{|c|c|c|c|c|c|c|c|c|c|c|c|c|}
\hline \multirow[b]{2}{*}{ Charge } & \multirow[b]{2}{*}{ Year } & \multirow[b]{2}{*}{ Place of Trial } & \multirow[b]{2}{*}{ Judge } & \multirow[b]{2}{*}{ Accused } & \multicolumn{6}{|c|}{ MAKE UP OF JURY } & \multirow[b]{2}{*}{ Verdict } & \multirow[b]{2}{*}{ Remarks } \\
\hline & & & & & 芯 & 褐 & 量 & 駌 & 恶 & $\begin{array}{l}\text { d } \\
\text { 5 }\end{array}$ & & \\
\hline S.206 & 1955 & Yellowknife & Sissons & Eskimo & 6 & & & & & 6 & Not Guilty & \\
\hline S. 137 & 1956 & Ft. Smith & Sissons & White & 6 & & & & 1 & 5 & Not Guilty & \\
\hline S.136 & 1956 & Hay River & Sissons & White & 6 & & & & & 6 & Indecent Assault & \\
\hline S.206 & 1957 & Cambridge Bay & Sissons & Eskimo & 6 & & & & & 6 & Not Guilty & \\
\hline S.206 & 1957 & Ft. Smith & Sissons & White & 6 & & & & 1 & 5 & Manslaughter & $\begin{array}{l}\text { Strong recommendation } \\
\text { for leniency }\end{array}$ \\
\hline 5.210 & 1957 & Yellowknife & Sissons & White & 6 & & & & & 6 & Not Guilty & \\
\hline S.210 & 1957 & Yellowknife & Sissons & White & 6 & & & & & 6 & $\begin{array}{l}\text { Intent to do } \\
\text { bodily harm }\end{array}$ & \\
\hline S. 192 & 1957 & Aklavik & Sissons & Eskimo & 6 & & 1 & 1 & & 4 & Not Guilty & \\
\hline S. 137 & 1957 & Yellowknife & Sissons & White & 6 & & & & & 6 & Guilty & \\
\hline S.206 & 1958 & Rankin Inlet & Sissons & White & 6 & & 2 & & & 4 & Not Guilty & (1) \\
\hline S. 192 & 1958 & Rankin Inlet & Sissons & White & 6 & & 1 & & & 5 & Not Guilty & (1) (2) \\
\hline S. 189 & 1958 & Rankin Inlet & Sissons & Eskimo & 6 & & 1 & & & 5 & Not Guilty & (1) (2) \\
\hline S.292 & 1959 & Yellowknife & Sissons & White & 6 & & & & & 6 & Not Guilty & \\
\hline S. 136 & 1959 & Hay River & Sissons & White & 6 & & & & & 6 & Not Guilty & \\
\hline S. 136 & 1959 & Aklavik & Sissons & Metis & 6 & & & 1 & 1 & 4 & Attempted Rape & \\
\hline S.136 & 1960 & Aklavik & Sissons & Metis & 6 & & & 1 & & 5 & Not Guilty & \\
\hline
\end{tabular}




\begin{tabular}{|c|c|c|c|c|c|c|c|c|c|c|c|}
\hline S. 206 & 1960 & Cambridge Bay & Sissons & Eskimo & 6 & 2 & & & 4 & Manslaughter & \\
\hline S.210 & 1960 & Ft. Smith & Sissons & White & 6 & & & & 6 & Causing bodily harm & \\
\hline S.206 & 1961 & Yellowknife & Sissons & White & 6 & & & & 6 & Manslaughter & \\
\hline S. 136 & 1961 & Yellowknife & Sissons & Metis & 6 & & & & 6 & Indecent Assault & \\
\hline S. 189 & 1961 & Baker Lake & Sissons & Eskimo & 6 & & & & 6 & Not Guilty & (3) \\
\hline S. 145 & 1961 & Baker Lake & Sissons & Eskimo & 6 & 1 & & & 5 & Guilty & (3) \\
\hline S. 296(a) & 1962 & Yellowknife & Sissons & Indian & 6 & & & & 6 & Not Guilty & \\
\hline S. 207 & 1962 & Yellowknife & Primrose & White & 6 & & & & 6 & Guilty & retrial \\
\hline S. 141(1) & 1962 & Yellowknife & Sissons & White & 6 & & & & 6 & Not Guilty & \\
\hline S. 288 & 1962 & Ft. Smith & Sissons & Metis & 6 & & & 1 & 5 & Not Guilty & \\
\hline S. 138(1) & 1962 & Yellowknife & Parker & White & 6 & & & & 6 & Indecent Assault & \\
\hline S. 297 & 1962 & Yellowknife & Parker & Indian & 6 & & & & 6 & Guilty & \\
\hline S. $231(1)(a)$ & 1963 & Hay River & Sissons & White & 6 & & & & 6 & Not Guilty & \\
\hline S. 372(4) & 1963 & Yellowknife & Sissons & White & 6 & & & & 6 & Not Guilty & \\
\hline S. $372(4)$ & 1963 & Yellowknife & Sissons & White & 6 & & & & 6 & Not Guilty & \\
\hline S. 323 & 1963 & Inuvik & Sissons & White & 6 & & & 1 & 5 & Not Guilty & two accused \\
\hline S. 137 & 1963 & Ft. McPherson & Sissons & Indian & 6 & 1 & 1 & 2 & 2 & Guilty & \\
\hline S. 207 & 1964 & Ft. Simpson & Sissons & Indian & 6 & & & 1 & 5 & Not Guilty & \\
\hline S. 136 & 1964 & Yellowknife & Sissons & White & 6 & & & & 6 & Guilty & \\
\hline S. 304 & $19 \subseteq 5$ & Yellowknife & Sissons & White & 6 & & & & 6 & Not Guilty & \\
\hline S. 207 & 1965 & Yelloknife & Sissons & Indian & 6 & & & & 6 & Guilty & recommended leniency \\
\hline S. 207 & 1965 & Ft. Smith & Sissons & Indian & 6 & & & & 6 & Guilty & \\
\hline S. 280(a) & 1965 & Inuvik & Sissons & Indian & 6 & 2 & & & 4 & Not Guilty & $(4)$ \\
\hline S. 297(a) & 1965 & Inuvik & Sissons & Indian & 6 & 2 & & & 4 & Not Guilty & (4) \\
\hline
\end{tabular}


TABLE I (Continued)

MAKE UP OF JURY

\begin{tabular}{|c|c|c|c|c|c|c|c|c|c|c|c|c|}
\hline \multirow[b]{2}{*}{ Charge } & \multirow[b]{2}{*}{ Year } & \multirow[b]{2}{*}{ Place of Trial } & \multirow[b]{2}{*}{ Judge } & \multirow[b]{2}{*}{ Accused } & & & & & & & \multirow[b]{2}{*}{ Verdict } & \multirow[b]{2}{*}{ Remarks } \\
\hline & & & & & 营 & $\begin{array}{l}\text { 营 } \\
\text { 总 }\end{array}$ & $\begin{array}{l}\text { 号 } \\
\text { 营 }\end{array}$ & 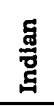 & 总 & $\begin{array}{l}\text { 岕 } \\
\text { ठే }\end{array}$ & & \\
\hline S. 136 & 1966 & Hay River & Parker & Metis & 6 & & & & & 6 & Not Guilty & \\
\hline S. 206(1) & 1966 & Spence Bay & Sissons & Eskimo & 5 & 1 & 3 & & & 3 & Manslaughter & (5) \\
\hline S. 206(1) & 1966 & Spence Bay & Sissons & Eskimo & 5 & 1 & 3 & & & 3 & Not Guilty & (5) \\
\hline S. 141 & 1966 & Yellowknife & Morrow & Indian & 6 & & & & & 6 & Guilty & \\
\hline S. 141 & 1966 & Yellowknife & Morrow & White & 6 & & & & & 6 & Not Guilty & \\
\hline S. 141 & 1966 & Yellowknife & Morrow & White & 6 & & & & & 6 & Guilty & \\
\hline S. 136 & 1966 & Tuktoyaktuk & Morrow & Eskimo & 6 & & 2 & & & 4 & Not Guilty & \\
\hline S. 136 & 1966 & Inuvik & Morrow & Eskimo & 6 & & & & & 6 & Attempted Rape & \\
\hline S.216(a) & 1961 & Ft. Smith & Morrow & White & 6 & & & & & 6 & Not Guilty & \\
\hline$\overline{\mathrm{S.} 192}$ & 1967 & Hay River & Morrow & White & 5 & 1 & & & & 6 & Dangerous Driving & \\
\hline S.138(1) & 1967 & Rankin Inlet & Morrow & Eskimo & 6 & & 4 & & & 2 & Guilty & \\
\hline S. 141(1) & 1967 & Yellowknife & Morrow & Indian & 4 & 2 & & & & 6 & Not Guilty & \\
\hline S. 136 & 1969 & Yellowknife & Morrow & Indian & 4 & 2 & & & & 6 & Not Guilty & \\
\hline S. 138(1) & 1967 & Yellowknife & Morrow & White & 3 & 3 & & & & 6 & Attempt & \\
\hline S. 136 & 1967 & Aklavik & Morrow & Indian & 5 & 1 & 3 & 2 & 1 & & Not Guilty & First all Native Jury \\
\hline S. 374 & 1967 & Frobisher Bay & Morrow & Eskimo & 4 & 2 & 2 & & & 4 & Not Guilty & Female accused \\
\hline S. 136 & 1967 & Inuvik & Morrow & Eskimo & 4 & 2 & 1 & & 1 & 4 & Not Guilty & (6) \\
\hline S. 136 & 1968 & Yellowknife & Morrow & Metis & 6 & & 1 & & & 5 & Guilty & \\
\hline
\end{tabular}




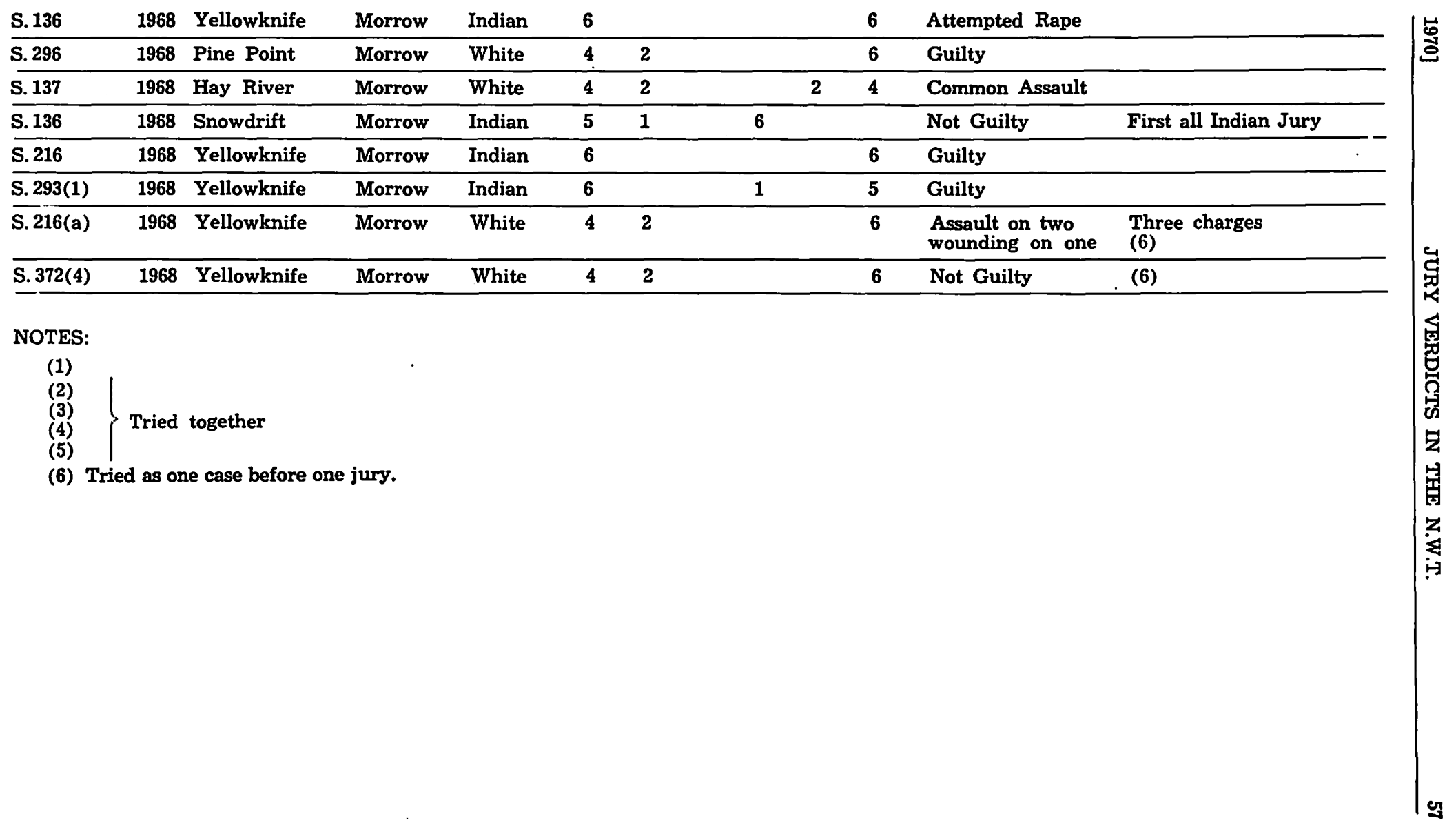


TABLE II

$\begin{array}{ll}\text { Total Charges } & 68 \\ \text { Convicted as Charged } & 16 \\ \text { Reduced Charge } & 17 \\ \text { Acquitted } & 35\end{array}$

TABLE III

(Murder, Sec. 206)

\begin{tabular}{|c|c|c|c|c|}
\hline Accused & Convicted & Acquitted & $\begin{array}{l}\text { Reduced } \\
\text { Charge }\end{array}$ & $\begin{array}{c}\text { No. case with } \\
\text { natives on Jury }\end{array}$ \\
\hline $\begin{array}{ll} & \text { White } \\
\text { \# Indian } \\
\text { \# Metis } \\
\text { Eskimo }\end{array}$ & & 4 & 2 & 1 \\
\hline
\end{tabular}

Note: \# None charged.

TABLE IV

(Rape, Sec. 136)

\begin{tabular}{lccccc}
\hline \hline Accused & Convicted & Acquitted & $\begin{array}{c}\text { Reduced } \\
\text { Charge }\end{array}$ & $\begin{array}{c}\text { No. cases } \\
\text { Women on Jury }\end{array}$ & $\begin{array}{c}\text { No. cases with } \\
\text { Natives on Jury }\end{array}$ \\
\hline White & 1 & 1 & 1 & & \\
Indian & & 3 & 3 & 4 & 2 \\
Metis & 1 & 2 & 2 & & 3 \\
Eskimo & & 2 & 1 & 1 & 2 \\
\hline
\end{tabular}

